University of Rome for twenty-nine years, and especially on Ge'ez and Tigrinya, he also made important contributions to the study of other linguistic families, extracting from the note-books of various explorers elements on hitherto unknown languages, both Hamitic and Nilotic. As a historian, his most important achievement is the Storia d'Etiopia, from its origins to the thirteenth century, the only work on the subject based on a critical examination of the sources, both classical and medieval, oriental and western. As a civil servant, from 1899 to 1903 , he contributed to one of the initial stages of the pacification of Eritrea. The spirit in which he accomplished this task still lives in that remarkable treatise, Principi di diritto consuetudinario dell' Eritrea-a rich and accurate description of the laws and customs of many different tribes, informed by an intuitive understanding of the spirit of the indigenous culture.

'A member of many learned societies and academies, both Italian and foreign, he was for many years a member of the International African Institute, and served on its Executive Council. For his profound knowledge of African problems, his immense scientific production, and especially for his understanding and sympathy towards the Africans themselves, he will be remembered as one of the leading Africanists of our time.'

\title{
DR. THOMAS JESSE JONES
}

WWE regret to announce the death on 5 January 1950 of Dr. Jesse Jones, whose work for education, and particularly that of African peoples, has been one of the great influences in the development of African societies. Dr. Jesse Jones was for thirty-three years connected with the Phelps-Stokes Fund, first as its Educational Agent, and from 1917 to 1946 as its Educational Director. He was head of the PhelpsStokes Fund Educational Commission which in 1920, at the request of the Foreign Missions Conference of North America and the Conference of Missionary Societies of Great Britain and Ireland, visited West, South, and Equatorial Africa to study the educational, economic, social, and religious conditions of the African peoples of those areas. He edited the Commission's report which was published in 1922, and, as a result, was invited by the British Colonial Office to make a similar study in British East Africa. The report of this inquiry, Education in East Africa, was published in London in 1925. These reports were influential in the formation of the Colonial Office Advisory. Committee on Education in the Colonies, of which Sir Hanns Vischer, the first Secretary-General of this Institute, was Secretary. 